\title{
PENDIDIKAN KARAKTER BAGI PELAKU PEDOFILIA (SEBUAH STRATEGI DALAM MENGATASI AMORAL)
}

\author{
${ }^{1}$ Heri Cahyono, ${ }^{2}$ Suhono, \& ${ }^{3}$ Aisyah Khumairo \\ ${ }^{1}$ Fakultas Agama Islam Universitas Muhammadiyah Metro ${ }^{2}$ Institut Agama Islam Ma'arif \\ NU (IAIMNU) Metro ${ }^{3}$ Institut Agama Islam Negeri Metro (IAIN) Metro \\ e-mail: ${ }^{1}$ hericahyono808@gmail.com, ${ }^{2}$ suhono120708@gmail.com, \\ aisahkhumairo@gmail.com
}

\begin{abstract}
High intensity sexual violence of children in Indonesia, especially pedophilia has taken a lot of attention among academics and society. The aim of this research was to provide insights and thoughts about education character for pedophile actors as a strategy in dealing with immoral problems, and expected to be a reference as society and academics in implementing character education among pedophiles. This reserach was a literature review that sees pedophiles as serious issues that need to be resolved quickly through the concept of education character. Where educators in carrying out character education need to use some strategies such as moral feeling and loving, moral acting, moral modeling and repentance (back) to our God.
\end{abstract}

Keywords: Education Character; Pedophile Actors; Problem Solving of Imooral

\section{PENDAHULUAN}

Fenomena pedofilia yang tengah terjadi di bumi nusantara ini, merupakan ancaman yang nyata bagi keselamatan dan keamanan anak-anak di Indonesia.Ancaman pedofilia bukanlah mitos yang diciptakan oleh sekelompok orang, tetapi hal tersebut nyata adanya di Indonesia. Kita bisa menyimakkasus pedofilia yang sempat viral melalui grup Facebook Official Candy's $18+$. Begitu juga kasus pedofilia yang terjadi di Bogor, pelaku yang berinisial IR (17) diduga telah melakukan pencabulan terhadap GA (7), tidak lepas juga dengan kasus yang terjadi di Metro pada April 2016 kasus pedofilia terjadi terhadap NA seorang anak yang sedang duduk di kursi taman kanakkanan (TK) bahkan timbul keperihatinan para akademisi kota metro terhadap tindakan-tindakan pelecehan tersebut dengan

29 dosen mengirimkan surat terbuka kepada DPRD Metro (29 Dosen Kirim Surat Terbuka ke Wali Kota Metro). Kejadian ini terus merambah ke beberapa daerah, salah satunya adalah di Karanganyar, pemuda bernama Fajar diduga menyodomi 16 anak laki-laki di bawah umur.

Ironisnya, kejahatan seksual terhadap anak tidak saja untuk memenuhi hasrat seksual, tetapi juga dijadikan sebagai industri yang bisa memberikan keuntungan.Videovideo perlakuan cabul terhadap anak begitu bebas diperjual belikan di dunia maya. Siapapun bisa mengkonsumsinya dengan berbayar, bahkan ada juga situs-situs khusus yang menyediakan secara gratis. Kejahatan semacam ini bisa dikatakan sebagai extra ordinary crime, karena hal tersebut 
memberikan dampak yang besar bagi Indonesia. Pertama, anak-anak yang menjadi korban bisa mengalami trauma, malu dan bisa jadi depresi. Kedua, penyebaran dokumentasi kejahatan seksual tersebut bisa mengacaukan karakter generasi penerus bangsa. Ketiga, adanya pelaku pedofilia yang memperjualbelikan videonya, dapat membuat orang-orang tergiur dan besar kemungkinan turut melakukan hal serupa. Sehingga Dampak kejahatan seksual ini dapat bertahan dalam jangka panjang dan dapat mengakibatkan penyakit atau gangguan psikologis di kemudian hari (Probosiwi \& Bahransyaf, 2010).

Cermin karakter buruk yang ditampilkan secara nyata oleh segelintir orang ini dapat merusak citra bangsa yang religius dan bermartabat. Mereka bisa membawa dampak yang besar terhadap revolusi karakter bangsa Indonesia, yang tadinya sudah baik menjadi masyarakat berkarakter pedofilia. Karena bisa jadi kelompok pedofilia ini menjadi gerakan untuk mendoktrin para generasi muda untuk menjadi pedofil dan menyebarkan gerakan pedofilia di Indonesia.

Di sinilah letak persoalan pembangunan karakter baik di Indonesia. Pendidikan karakter selalu dianggap gagal manakala ada segelintir orang yang berbuat asusila terhadap anak-anak di bawah umur. Perlu diketahui, bahwa pendidikan karakter adalah proses, bukan tujuan. Maka dalam hal ini, pendidikan karakter akan tetap terus dilaksanakan, terutama saat ini bagi para pelaku pedofilia untuk mengembalikan para pelaku pedofilia ke fitrahnya.

In Modern era, science is needed to human being in order to be useful people. So we as the people always hope to our god to be the better people to face some problem in the world (Suhono, 2017). Kutipan di atas mendesrkipsikan betapa pentingnya pendidikan, seperti halnya pendidikan karakter. Agama Islam, yang sejatinya sebagai sumber pendidikan karakter bagi umat Islam, harus benar-benar diurai dengan lebih detail penerapannya untuk menyadarkan pelaku pedofilia dan menjadikan mereka berkarakter baik. Oleh karena itu, kita harus secepat kilat mengambil tindakan tegas untuk melawannya. Jangan biarkan gerakan yang berbahaya ini berkembang biakmengancam anak-anak dan menebarkan karakter pedofilia di Indonesia. Melalui permasalahan di atas maka penulis mencoba mengungkap bagaimana pendidikan karakter bagi pelaku pedofilia dan bagaimana melindungi anak dari pelaku pedofilia.

\section{PENGERTIAN DAN KLASIFIKASI PEDOFILIA}

Pedofil atau pedofilia merupakan kata yang berasal dari bahasa yunani Paidophilia yang artinya kelainan perilaku 
pada seseorang yaitu perilaku peyimpangan seksual, biasanya seseorang yang menderita pedofil akan menyukai anak-anak sebagai sasarannya. Kata tersebut terdiri dari dua kata, yaitu pais yang artinya anak-anak dan philia yang artinya cinta yang bersahabat atau bisa dikatakan persahabatan, sehingga ketika diterapkan dalam perilaku bisa ditunjukkan dengan menyayangi anak atau dengan memiliki relasi yang mutualisme dengan anak-anak.Pedofilia merupakan gangguan nafsu seksual secara kontinyu terhadap remaja atau anak kecil, yang biasanya berusia di bawah 14 tahun atau lebih muda (Samiadi). Perilaku menyayangi terhadap anak-anak sebenarnya merupakan hal baik yang harus selalu dilestarikan bagi setiap insan di Indonesia bahkan dunia. Dalam dunia pendidikan, kasih sayang seringkali digunakan sebagai salah satu trik untuk mencapai keberhasilan pembelajaran dalam mata pelajaran tertentu. Begitu juga di lingkungan masyarakat, hal tersebut sangat dijunjung tinggi sebagai manifestasi dari kepedulian terhadap anak-anak.

Namun karena kasih sayang atau persahabatan dengan anak-anak disalah gunakan sebagai trik untuk melakukan perbuatan yang amoral terhadap anak-anak, maka pedofilia dianggap sebagai kelainan perilaku seseorang. Para pelaku pedofilia tidak hanya berjenis kelamin laki-laki, tetapi juga perempuan. Dalam praktiknya, perilaku ini bisa dilakukan oleh laki-laki terhadap anak-anak laki-laki atau perempuan, begitu juga pelaku perempuan bisa melakukan hal yang sama dengan seperti pelaku laki-laki (Probosiwi \& Bahransyaf, 2015: 113).

Hasrat seksual seseorang yang menggebu-gebu, seringkali menjadikan anak-anak atau remaja sebagai korban dari hasratnya tersebut, sehingga tidak sedikit anak-anak yang menjadi korban perilaku pedofilia.

Jika sudah demikian, maka akan semakin banyak anak-anak yang menjadi korban pedofilia. Anak-anak akan semakin ketakutan, mereka tidak bisa bebas lagi untuk bermain dan berkarya bersama teman sebayanya. Hal ini tentu akanberdampak buruk bagi perkembangan anak-anak, mereka akan mengganggap orang-orang yang lebih tua sebagai orang yang jahat. Anak-anak akan selalu curiga terhadap orang-orang yang lebih dewasa, dan bahkan tidak mempercayainya.

Dengan demikian, pedofilia dapat diklasifikasikan dalam dua macam. Namun klasifikasi yang lebih luas berdasarkan kepada jenis kelamin korban. Jika pedofil memiliki objek seksual berjenis kelamin yang berbeda, maka hal tersebut disebut heteroseksual (heterosexualpedhopile), sedangkan pedofil yang memiliki ketertarikan kepada sesama jenis, disebut 
pedofilia homoseksual (homosexual nampaknya tidak bisa menandingi jumlah pedhopile). keumuman bagi pelaku yang masih lajang. Gebhard dalam penelitiannya menemukan

\section{KARAKTERISTIK PEDOFILIA}

Karakteristik ialah seseorang atau sesuatu yang memiliki kekhususan atau kekhasan (Tim Pustaka Phoenix, 2010: 413). Namun Handayani (2010) Secara khusus, karakteristik pedofilia yang bisa disematkan kepada seseorang ini kadang tidak komplit dalam menyebutkan. Terkadang penjelasan mengenai karakteristik ini didasarkan kepada pelaku pedofilia tertentu, sehingga tidak menyasar kepada pelaku pedofilia lainnya. Persoalan karakteristik pada setiap pelaku pedofilia ini tidak bisa serta-merta disamaratakan, karena mereka berangkat dari motif yang berbeda dengan menggunakan cara yang berbeda pula.

Bagi pelaku pedofilia heteroseksual, dia memiliki status sosio-ekonomi, pendidikan dan pekerjaan yang lebih rendah dibandingkan dengan populasi yang normal.Selain itu, umumnya pelaku pedofilia tidak memiliki riwayat kriminal.Ini artinya bahwa pelaku pedofilia sebenarnya tidak memiliki perbedaan yang signifikan dengan populasi normal, karena para pelaku memiliki sikap yang baik tentang hal lainnya.

Umumnya pelaku pedofilia ini telah menikah dan terdapat permasalahan dari pernikahan tersebut. Keumuman tersebut bahwa mayoritas pelaku pedofilia

heteroseksual ini telah menikah dalam waktu yang relatif lama dan tidak stabil. Ketika pelaku melakukan serangan, hanya ada $31 \%$ yang berstatus menikah dan $41 \%$ belum pernah menikah (Khaidir, 2011). Di antara sekian jumlah pelaku pedofilia heteroseksual, bahwa mereka kesulitan melakukan kontak kepada sesama manusia, mereka merasa malu dan bertingkah laku yang tidak lazim (Khaidir, 2011).

Sedangkan karakteristik bagi pelaku pedofilia homoseksual ialah a) memiliki riwayat perilaku homoseksual sebelum menjadi pelaku; b) tertarik kepada sesama jenis yang usianya masih anak-anak. Riwayat homoseksual ini bukan saja sebagai pelaku, tetapi juga ketika seseorang menjadi korban dari keganasan homoseksual, adapat menjadikan dirinya bertindak sebagai pedofilia yang homoseksual.

Sekalipun demikian, karakteristik secara umum yang disematkan kepada para pelaku pedofilia yang banyak diungkap dari kasus-kasus pedofilia dapat dirangkum menjadi beberapa karakteristik, yaitu pria dewasa seringkali terlihat seperti orang pekerja keras, bersifat seperti orang tua yang sayang anak, memiliki kecenderungan berpendidikan tinggi dan religious dan 
memiliki sikap yang baik sehingga cenderung disukai oleh orang tua dan anakanak (Anindyakirana, 2014: 33). Sedangkan menurut Doni (2010: 67) pelaku pedofilia atau disebut pedofil, memilik ciri-ciri yang harus diketahui adalah terlalu obsesif, layaknya predator dan estrovet.

Memiliki Obsesi yang Tinggi.Obsesi adalah gangguan pikiran yang selalu menggoda seseorang dan sukar dihilangkan. Adanya gangguan pikiran ini tidak lepas dari pengaruh perilaku dan perkataan seseorang atau lingkungan sekitarnya. Obsesi yang dimiliki oleh pelaku pedofilia ini cenderung berlebihan, dia akan tetap terus mengejar sasaran yang telah dibidiknya hingga mendapatkannya. Jika belum mendapatkan sasaran tersebut, dia tidak berhenti mengejarnya dengan melakukan berbagai cara. Sasaran dalam hal ini adalah anak-anak prapubertas yang tidak menaruh curiga apapun ketika didekati oleh pelaku.

Bersifat seperti predator, pelaku pedofilia ini memiliki sifat layaknya predator yang siap memangsa sasarannya. Siapapun yang ada dalam pandangan matanya, maka dia akan berusaha mendapatkannya sebagai korban. Seperti halnya Emon, yang dalam pengakuannya menyebutkan jika ada anak yang masuk ke kolam renang Lio Santa akan disergapnya. Ini artinya, ketertarikan pelaku pedofilia memang tidak ditentukan sebelumnya, dia lebih fleksibel dalam mencari mangsa. Ketika mangsanya sudah ditentukan, dia akan berusaha untuk bisa mendapatkannya saat itu juga.

Introver, introver adalah sifat tertutup, pelaku pedofilia memilikisifat yang suka memendam rasa dan pikiran diri sendiri serta tidak diutarakan kepada orang lain. Penyematan ciri ini bukan berarti semua orang yang tertutup dikatakan pedofil, namun pada umumnya pelaku pedofilia memiliki ciri yang tertutup dan tidak bersosialisasi kepada masyarakat lainnya.

Pelaku pedofilia dalam mendekati anak-anak tidak ceroboh, sebagaimana karakteristiknya yang memiliki obsesi tinggi, dia mendekati anak-anak dengan cara-cara yang halus. Anak-anak tidak menyukai cara yang kasar, karena mereka sangat membutuhkan belaian kasih sayang dari orang yang lebih dewasa. Maka hal tersebut termasuk celah bagi para pelaku pedofilia dalam merayu anak-anak. Pelaku bisa melakukan hal-hal di bawah ini.

1. Para pelaku aktif mendekati anak-anak yang cenderung pendiam, kurang perhatian, terlihat lemah dan sedang ada masalah di rumah atau di sekolah.Anakanak yang seperti ini sangat membutuhkan perhatian dan kasih sayang dari orang yang lebih dewasa. Pada momen itulah para pelaku ini sering mengeluarkan jurus rayuan dan iming-iming sesuat, sehingga anak-anak 
tidak sadar jika hal tersebut termasuk jeratan.

2. Membangun kepercayaan anak dan orangtua dengan cara memberikan perhatian yang lebih terhadap anakanak. Jika kepercayaan anak dan orang tua tinggi, maka mereka tidak akan menaruh curiga terhadap pelaku pedofilia, dia akan dengan leluasa melancarkan aksinya terhadap anak.

3. Para pelaku selalu mencari alasan untuk memberi bimbingan atau hukuman terhadap anak-anak agar dirinya selalu berdua dengan mereka di tempat-tempat yang telah ditentukan sebelumnya. Pada poin inilah, para pelaku pedofilia dianggap menculik anak-anak, karena pada waktu-waktu tertentu dia membawa anak-anak di tempat tersembunyi yang asing bagi anak.

4. Kepolosan anak-anak dalam hal ini, banyak dimanfaatkan oleh mereka. Mereka terlihat penyayang anakdan perhatian, sehingga untuk mendekatinya tidak dengan kekerasan, tetapi dengan rayuan dan ancaman (Anindyakirana, 2014).

Cara yang halus ini hampir tidak dicurigai oleh siapapun, karena dengan karakteristiknya yang pendiam, maka mayoritas masyarakat menganggap bahwa pelaku pedofilia merupakan orang yang baikbaik saja. Ini artinya, karakteristik pendiam dan penyayang terkadang secara keseluruhan ditafsirkan sebagai orang baik, sedangkan orang-orang yang banyak bicara dan tidak terlalu menyukai anak-anak dikatakan tidak pantas jadi orang tua.

Karakter yang demikian, jika terus berlanjut dibiarkan, maka itu akan menjadi konsumsi primer dalam keseharian. Semua kasus pedofilia yang telah terungkap, nyatanya pelaku pedofilia telah melakukannya lebih dari satu anak.Itu baru satu pelaku, sedangkan pelaku yang tertangkap terdiri dari anggota kelompok pedofilia, tentu saja mereka akan menyebar untuk mencari mangsa sesuai tugasnya.

\section{METODE PENELITIAN}

Jenis penelitian yang digunakan dalam penelitian ini adalah kepustakaan (Library Research) dimana penulis menggunakan pendekatan penelitian normatif deskriptif dengan lebih menekankan pada kekuatan analisis data pada sumber-sumber data yang ada. Yang dimaksud dengan studi kepustakaan adalah segala usaha yang dilakukan oleh peneliti untuk menghimpun informasi yang relevan dengan topik atau masalah yang akan atau sedang diteliti. Informasi itu dapat diperoleh dari buku-buku ilmiah, laporan penelitian, karangan-karangan ilmiah, tesis, disertasi, peraturan-peraturan, ketetapanketetapan, buku tahunan, ensiklopedia, dan 
sumber-sumber tertulis lain baik tercetak maupun elektronik.

Sumber-sumber data dapat dibagi menjadi dua kategori, yaitu sumber data primer dan skunder. Sumber data primer dalam penelitian ini adalah Pendidikan Karakter Panduan Lengkap Mendidik Siswa Menjadi Pintar dan Baik Karya Thomas Lickona. Filsafat Pendidikan Islam Menuju Pembentukan Karakter Menghadapi Arus Global, Karya Maragustam. Adapun sumber skundernya adalah segala informasi yang berkaitan dengan tema penelitian ini, baik berupa buku maupun artikel-artikel yang tersebar di berbagai makalah dan web-site.

Pengumpulan data dalam penelitian ini dilakukan dengan teknik dokumentasi. Teknik ini digunakan untuk melacak dokumen, data dan informasi baik yang berupa buku, majalah, jurnal ilmiah, artikel, dan lain sebagainya yang relevan dengan penelitian ini.

Untuk menganalisis data, penulis menggunakan content analysis (analisis isi) sebagaimana dikutip oleh Burhan Bungin (2003:173) mengatakan bahwa content analysis adalah suatu metodologi penelitian yang memanfaatkan seperangkat prosedur untuk menarik kesimpulan yang sahih dari sebuah buku atau dokumen.

\section{HASIL PENELITIAN DAN PEMBAHASAN}

Pendidikan karakter adalah sebuah usaha yang dilakukan secara sengaja untuk mendidik individu agar dapat mengambil keputusan bijak dan mempratikkannya dalam kehidupan sehari-hari, sehingga mereka dapat memberikan kontribusi yang positif kepada lingkungannya (Megawangi, 2004: 95). Menurut Wulandari dan Kristiawan (2017) pendidikan karakter merupakan gerakan nasional untuk menciptakan sekolah yang membina generasi muda yang beretika, bertanggung jawab, dan peduli. Pendidikan karakter juga bukan hanya sekedar mengajarkan mana yang benar dan mana yang salah. Lebih dari itu, pendidikan karakter adalah usaha menanamkan kebiasaan-kebiasaan yang baik (habituation) (Kristiawan, 2016) sehingga siswa mampu bersikap dan bertindak berdasarkan nilainilai yang telah menjadi kepribadiannya. Kristiawan (2015) berpendapat bahwa Indonesia needs revitalization and strengthening strong character of human resources. One aspect that can be done to prepare for the strong human character is through education.

Ahmad ddk (2017) menjeaskan

Proses pembentukan karakter dimulai dari pengenalan perilaku baik dan buruk dan pembiasaan perilaku baik dalam kehidupan sehari-hari. Pada usia pra sekolah, pendidikan karakter efektif dilakukan oleh 
keluarga. Oleh sebab itu, penting sekali bagi keluarga baru yang memiliki anak usia di bawah lima tahun untuk memberi lingkungan belajar yang terbaik di rumah. Orang tua harus meluangkan waktunya untuk mendidik anak-anak (Ahmad, et. al. 2017). Pendidikan karakter anak usia Sekolah Dasar sangat efektif dilakukan di sekolah. Lingkungan sekolah (guru dan siswa) memiliki peran yang kuat dalam membentuk karakter anak. Sedangkan Pendidikan karakter menurut Maragustam (2010: 245) ialah mengukir dan mempraktikkan nilai-nilai ke dalam diri peserta didik melalui pendidikan, endapan pengalaman, pembiasaan, aturan, rekayasa lingkungan dan pengorbanan dipadukan dengan nilai-nilai intrinsik yang sudah ada dalam diri peserta didik sebagai landasan dalam berpikir, bersikap dan perilaku secara sadar dan bebas. Selanjutnya dalam mengimplementasikan pembelajaran karakter di antaranya menerapkan metode pembelajaran yang melibatkan partisipatif aktif siswa, (2) menciptakan lingkungan belajar yang kondusif, (3) memberikan pembelajaran karakter secara eksplisit, sistematis, dan berkesinambungan dengan melibatkan aspek knowing the good, loving the good, and acting the good, dan (4) memperhatikan keunikan siswa masingmasing dalam menggunakan metode pembelajaran, yaitu menerapkan kurikulum yang melibatkan 9 aspek kecerdasan manusia
(Ahmad et al., 2017). Akhirnya menurut Renata dkk (2017) pendidikan karakter adalah sebuah sistem yang menanamkan nilai-nilai karakter pada peserta didik, yang mengandung komponen pengetahuan, kesadaran individu, tekad, serta adanya kemauan dan tindakan untuk melaksanakan nlai-nilai, baik terhadap Tuhan Yang Maha Esa, diri sendiri, sesama manusia, lingkungan, maupun bangsa, sehingga akan terwujud insan kamil.

Pendidikan karakter ini harus diimplementasikan kepada para pelaku pedofilia, sebagai upaya menghindarkan dari kehancuran suatu bangsa. Kehancuran sebuah bangsa dikemukakan oleh Thomas Lickona (2013) yang memiliki tanda-tanda 1) meningkatnya kekerasan dan suka merusak dikalangan remaja (violence and vandalism); 2) penggunaan kata atau bahasa yang cenderung memburuk (seperti ejekan, makian, celaan, bahasa slank dll) (bad language); 3) mudah terpengaruh dalam tindak kekerasan (peer cruetly); 4) meningkatnya prilaku penyalahgunaan seks, merokok dan obat-obat telarang dikalangan pelajar dan remaja (sexual procesity and abuse); 5) merosotnya prilaku moral dan meningkatnya egoisme pribadi yang mementingkan diri sendiri serta rendahnya rasa tanggung jawab (increasing self centeredness and declining civic responsibility); 6) menurunya rasa bangga, 
cinta bangsa dan tanah air (Patriotisme); 7) rendahnya rasa hormat pada orang lain, orang tua dan guru (disrespect for authority); 8) meningkatnya prilaku merusak kepentingan publik dengan terbiasa melakukan penipuan (Cheating); 9) ketidakjujuran terjadi dimana-mana (stealing); 10) berkembangnya rasa saling curiga, membenci dan memusuhi diantara sesama warga negara(self distructive behavior) (Lickona, 2013: 15).

Penyalahgunaan seksual menjadi sebuah persoalan bangsa yang perlu diatasi dengan diterapkannya pendidikan karakter. Adapun tujuan pendidikan karakter menurut Kemendiknas (2010: 7) ialah 1) mengembangkan potensi kalbu atau nurani (afektif) peserta didik sebagai manusia dan warga negara yang memiliki nilai-nilai budaya dan karakter bangsa; Mengembangkan kebiasaan dan prilaku keseharian peserta didik yang terpuji dan sejalan dengan nilai-nilai universal serta budaya bangsa religius.

Secara lebih luas, adanya pendidikan karakter bagi pelaku pedofilia dimaksudkan untuk 1) menyadarkan para pelaku pedofilia yang saat ini telah memakan banyak korban; 2) mengurangi jumlah pelakuaktif pedofilia di Indonesia; 3) melindungi anak-anak dari kejahatan pelaku pedofilia; 4) memberikan sosialisasi tentang pencegahan dan penanggulangan pedofilia di Indonesia melalui pendidikan karakter; 5) memberikan solusi nyata kepada para pelaku pedofilia untuk membangun rumah tangga yang bahagia.

Pelaksanaan pendidikan karakter bagi pelaku pedofilia ini berangkat dari hadis nabi إنََّّا بُعثت لأنمِّمَ مكارم الأخْلاق Artinya "Sesungguhnya saya (Muhammad) diutus hanyalah untuk menyempurnakan akhlak" (HR. al-Baihaqi, "Sunan al-Baihaqi" Juz II, Hadis No. 472). Dalam hadis lain yang diriwayatkan oleh Abdullah Ibn Amr juga disebutkan bahwa "Sebaik-baik kamu adalah orang yang paling baik akhlaknya" (HR. al-Tirmidzi). Selain itu, ada juga hadis yang menjelaskan "Sesungguhnya orang yang paling cinta kepadaku diantara kamu sekalian dan paling dekat tempat duduknya denganku di hari kiamat adalah yang terbaik akhlaknya diantara kamu sekalian" (HR. al-Tirmidzi).

Akhlak di sini tidak lain adalah karakter individu yang dituntut untuk baik. Suhono dan Ferdian menegaskan bahwa "akhlak terpuji serta kepribadian yang sesuai ajaran Islam, maka orang tua harus mendidiknya sedini mungkin dengan moral yang baik. Karena tiada yang lebih utama dari pemberian orang tua kecuali budi pekerti yang baik" (Suhono \& Utama, 2017). Contoh yang baik itulah yang akan ditiru oleh anak didik dalam prilaku dan akhlak, baik itu ia sadari maupun tidak. Bahkan 
dapat meresap dan mempengaruhi menjadi watak dalam diri mereka (Suhono \& Utama, 2017).

Keharusan menjunjung tinggi karakter mulia yang telah ditegaskan kepada umat manusia ini memiliki dua pesan, yaitu pesan untuk diri sendiri dan pesan sebagai agen pendidikan karakter bagi umat manusia, yang dalam hal ini ialah para pelaku pedofilia. Doni Kusuma (2010: 2015) menegaskan bahwa nilai-nilai yang harus ditanamkan kepada para pelaku pedofilia ini melibatkan berbagai macam komposisi nilai, di antaranya ialah nilai agama, nilai moral, nilai-nilai umum dan nilai-nilai kewarganegaraan. Kemendiknas (2010: 7-8) dalam panduan pendidikan karakter meringkas sumber nilai karakter itu menjadi empat sebagai berikut.

1. Agama, sumber nilai yang harus dipahami dalam hal ini ialah agama, karena agama ini merupakan pengendali karakter masyarakat. Di Indonesia, mayoritas masyarakat adalah masyarakat beragama, kehidupan individu, masyarakat, dan bangsa selalu didasari pada ajaran agama dan kepercayaan. Oleh karenanya nilai-nilai pendidikan budaya dan karakter bangsa harus di dasarkan pada nilai-nilai dan akidah yang berasal dari agama.
2. Pancasila, Pancasila sebagai ideologi negara, perlu dijadikan sebagai sumber nilai karakter bangsa.

3. Budaya, posisi budaya yang demikian penting dalam kehidupan masyarakat mengharuskan budaya menjadi sumber nilai dalam pendidikan budaya dan karakter bangsa.

4. Tujuan Pendidikan Nasional sebagai rumusan kualitas yang harus dimiliki setiap warga negara Indonesia, dikembangkan oleh berbagai satuan pendidikan diberbagai jenjang dan jalur. Oleh karenanya, tujuan pendidikan nasional adalah sumber yang paling operasional dalam pengembangan pendidikan budaya dan karakter bangsa.

Dari penjelasan di atas, maka unsurunsur utama pendidikan karakter yang harus ditanamkan kepada para pelaku pedofilia ialah:ketulusan hati atau kejujuran, belas kasih, kegagahberanian, kasih sayang, kontrol diri, kerja sama, kerja keras.

Dari tujuh unsur ini, unsur yang harus benar-benar ditanamkan kepada para pelaku pedofilia ialah mengenai kontrol diri. Kontrol diri ini menjadi hal yang paling bermasalah dalam diri pelaku pedofilia, karena segala kasih sayang dan persahabatan terhadap anak-anak disalahgunakan, ia membiarkan dirinya terjerumus ke dalam lembah yang nista. Karakter yang kurang bisa mengontrol diri sendiri akan berdampak 
buruk bagi diri sendiri dan masyarakat ada 18 nilai-nilai yang perlu dikembangkan sekitarnya. Oleh karena itu, hal tersebut melalui pendidikan karakter untuk harus diatasi dengan baik, karena manusia menginsyafkan para pelaku pedofilia yang bisa dikatakan baik jika karakternya bisa tidak memiliki tanggung jawab dan baik. Sedangkan Pusat Kurikulum kepedulian sosial, di antaranya ialah sebagai Kementrian Pendidikan Nasional yang berikut. diterbitkan pada tahun 2010 merumuskan

Tabel. 18 (Delapan Belas) Nilai Karakter

\begin{tabular}{|c|c|}
\hline Nilai & Deskripsi \\
\hline Religius & $\begin{array}{l}\text { Sikap dan perilaku yang patuh dalam melaksanakan ajaran } \\
\text { agama yang dianutnya, toleran terhadap pelaksanaan ibadah } \\
\text { agama lain dan hidup rukun dengan pemeluk agama lain. }\end{array}$ \\
\hline Jujur & $\begin{array}{l}\text { Perilaku yang didasarkan pada upaya menjadikan dirinya } \\
\text { sebagai orang yang selalu dapat dipercaya dalam perkataan, } \\
\text { tindakan agama dan pekerjaan. }\end{array}$ \\
\hline Toleransi & $\begin{array}{l}\text { Sikap dan tindakan yang menghargai perbedaan agama, suku, } \\
\text { etnis, pendapat, sikap dan tindakan orang lain yang berbeda } \\
\text { dari dirinya. }\end{array}$ \\
\hline Disiplin & $\begin{array}{l}\text { Tindakan yang menunjukan perilaku tertib dan patuh pada } \\
\text { berbagai ketentuan dan peraturan. }\end{array}$ \\
\hline Kerja Keras & $\begin{array}{l}\text { Perilaku yang menunjukan upaya sungguh-sungguh dalam } \\
\text { mengatasi berbagai hambatan belajar dan tugas sebaik-baiknya. }\end{array}$ \\
\hline Kreatif & $\begin{array}{l}\text { Berfikir dan melakukan sesuatu untuk menghasilkan cara atau } \\
\text { hasil baru dari sesuatu yang telah dimiliki. }\end{array}$ \\
\hline Mandiri & $\begin{array}{l}\text { Sikap dan perilaku yang tidak mudah tergantung pada orag lain } \\
\text { dalam menyelesaikan tugas-tugasnya. }\end{array}$ \\
\hline Demokratis & $\begin{array}{l}\text { Cara berfikir, bersikap dan bertindak menilai sama hak dan } \\
\text { kewajiban dirinya dan orang lain. }\end{array}$ \\
\hline Rasa Ingin Tahu & $\begin{array}{l}\text { Sikap dan tindakan yang selalu berupaya untuk mengetahui } \\
\text { lebih mendalam dan meluas dari sesuatu yang dipelajarinya, } \\
\text { dilihat dan didengar. }\end{array}$ \\
\hline Semangat & Cara berfikir, bertindak dan berwawasan yang menempatkan \\
\hline Kebangsaan & $\begin{array}{l}\text { kepentingan bangsa dan negara di atas kepentingan diri dan } \\
\text { kelompoknya. }\end{array}$ \\
\hline Cinta Tanah Air & $\begin{array}{l}\text { Cara berfikir, bersikap dan berbuat menunjukkan, kesetiaan, } \\
\text { kepedulian dan penghargaan tinggi terhadap bahasa, } \\
\text { lingkungan fisik, sosial, budaya, ekonomi dan politik bangsa. }\end{array}$ \\
\hline Menghargai & Sikap dan tindakan yang mendorong dirinya untuk \\
\hline Prestasi & $\begin{array}{l}\text { menghasilkan sesuatu yang berguna bagi masyarakat, mengakui } \\
\text { serta menghormati keberhasilan orang lain. }\end{array}$ \\
\hline $\begin{array}{l}\text { Bersahabat/ } \\
\text { Komunikatif }\end{array}$ & $\begin{array}{l}\text { Tindakan yang memperlihatkan rasa senang berbicara, bergaul } \\
\text { dan bekerjasama dengan orang lain. }\end{array}$ \\
\hline Cinta Damai & $\begin{array}{l}\text { Sikap, perkataan dan tindakan yang menyebabkan orang lain } \\
\text { merasa senang dan aman atas kehadiran dirinya. }\end{array}$ \\
\hline Gemar & Kebiasaan menyediakan waktu untuk membaca berbagai \\
\hline
\end{tabular}




\begin{tabular}{ll}
\hline Membaca & bacaan yang memberikan kebajikan bagi dirinya. \\
Peduli & Sikap dan tindakan yang selalu berupaya mencegah kerusakan \\
Lingkungan & alam lingkungan diantaranya dan mengembangkan upaya- \\
& upaya untuk memperbaiki kerusakan alam yang terjadi. \\
Peduli Sosial & $\begin{array}{l}\text { Sikap dan tindakan yang selalu ingin memberikan bantuan pada } \\
\text { orang lain dan masyarakat yang membutuhkan. }\end{array}$ \\
Tanggung & $\begin{array}{l}\text { Sikap dan prilaku seseorang untuk melaksanakan tugas dan } \\
\text { kewajibannya yang seharusnya ia lakukan terhadap dirinya } \\
\text { sendiri, masyarakat dan lingkungan (alam sosial dan budaya) }\end{array}$ \\
& negara dan Tuhan Yang Maha Esa. \\
\hline
\end{tabular}

bisa menggantikan karakter buruk para pelaku pedofilia yang selalu menebar ancaman kepada anak-anak. Kepatuhan terhadap agama menjadi kunci utama bagi para pelaku pedofilia agar dirinya kembali sempurna sebagaimana manusia biasanya. Namun penanaman nilai-nilai karakter di atas tidak mudah dilaksanakan, karena penanaman karakter tersebut terdapat berbagai langkah yang tidak mudah.

STRATEGI PENDIDIKAN KARAKTER BAGI PELAKU PEDOFILIA

Menurut Maragustam, ada enam strategi pendidikan karakter yang meliputi habitusasi (pembiasaan) dan pembudayaan yang baik, membelajarkan hal-hal yang baik (moral knowing), (moral feeling dan loving) merasakan dan mencintai yang baik, (moral acting) tindakan yang baik, keteladanan (moral modeling) dari lingkungan sekitar, harus dilaksanakan secara

berkesinambungan, baik secara berurutan maupun secara acak. Penjelasan mengenai enam strategi tersebut ialah (Maragustam: 264).

1. Habituasi (pembiasaan) dan pembudayaan hal-hal yang baik

Kebiasaan adalah sesuatu yang memberikan sifat dan jalan yang tertentu alam pikiran, keyakinan, keinginan dan kepercayaan, kemudian jika telah tercetak dalam sifat ini, seseorang sangat suka kepada pekerjaannya kecuali merubahnya dengan kesukaran. Adapun hukum pembiasaan itu melalui enam tahapan, yaitu 1) berpikir, seseorang mengetahui dan memikirkan nilainilai yang diberikan, lalu memberi perhatian dan berkonsentrasi pada nilai tersebut; 2) perekaman, setelah nilai-nilai diterima, otaknya merekam. Otaknya kemudian membuat file yang sejenis dengan pikiran itu dan menghubungkan dengan pikiran-pikiran lain, yang sejenis atau yang dinilai bermanfaat baginya; 3) pengulangan, yakni seseorang memutuskan untuk mengulangi 
nilai-nilai yang baik itu dengan perasaan yang sama; 4) penyimpanan, karena perekaman dilakukan berkali-kali terhadap perilaku nilai-nilai yang masuk tadi, pikiran menjadi semakin kuat; 5) pengulangan, disadari atau tidak, seseorang mengulang kembali nilai-nilai yang baik yang tersimpan kuat dalam akal bawah sadarnya. Ia dapat merasakan bahwa dirinya telah mengulangi perilaku itu atau terjadi begitu saja di luar kemauannya; 6) kebiasaan, kebiasaan menjadi karakter, karena pengulangan nilainilai yang baik yang berkelanjutan dan tahapan-tahapan di atas yang di lalui, akal manusia menyakini bahwa pembiasaan ini merupakan bagian terpenting dari perilaku.

2. Membelajarkan hal-hal yang baik Moral knowing

Kebiasaan-kebiasaan baik yang dilakukan atau yang belum dilakukan oleh seseorang, perlu diberi pemahaman dan pengetahuan yang komprehensif tentang manfaat dari kebiasaan yang dilakukan, rasionalisasi dan akibat dari nilai-nilai dan perilaku baik yang dilakukan. Dengan demikan, para pelaku pedofilia bisa mencoba mengetahui, memahami, menyadari dan berpikir logis tentang arti dari suatu nilainilai dan perilaku yang baik, kemudian mendalaminya dan menjiwainya.

3. Moral feeling dan loving merasakan dan mencintai yang baik

Lahirnya moral loving berawal dari mindset (pola pikir) yang positif terhadap nilai-nilai kebaikan yang dilakukan. Ketika para pelaku pedofilia ini merasakan betapa indahnya dan manfaatnya perilaku baik, maka dia bisa melahirkan rasa cinta terhadap perbuatan baik tersebut. Jika sudah mencintai hal yang baik, maka segenap dirinya akan berkorban demi melakukan yang baik itu. Perasaan cinta kepada kebaikan ini menjadi power dan engine yang bisa membuat para pelaku pedofiliaselalu ingin berbuat kebaikan, bahkan melebihi dari sekedar kewajiban sekaligus harus berkorban baik jiwa dan harta.

4. Moral acting tindakan yang baik

Strategi pembiasaan, berpikir mengenai kebaikan, merasa cinta kepada kebaikan dan pengalaman kebaikan, yang pada akhirnya bisa membentuk karakter karakter baik pada diri pelaku pedofilia. Tindakan kebaikan yang dilandasi oleh pengetahun, kesadaran, kebebasan dan kecintaan, bisa membentuk endapan pengalaman kebaikan di dalam diri pelaku pedofilia. Dari endapan itu akan terpatri dalam akal bawah sadar dan seterusnya menjadi karakter. Semakin diulangi hal yang baik, maka semakin kuat akarnya dalam jiwa dengan catatan tindakan yang baik itu diikuti dengan senang hati.

5. Keteladanan (moral modeling) dari lingkungan sekitar

Keteladanan dari orang yang lebih dewasa dibutuhkan sebagai model yang ideal. (Suhono \& Utama, 2017) memberikan 
contoh bahwa "Keteladanan guru dan orang tua sangat penting untuk diperhatikan dalam membimbing dan mendidik anak-anaknya. keberadaannya merupakan bagian yang integral dalam proses pendidikan dengan tujuan untuk membekali anak dalam memecahkan segala masalah-masalah kehidupan yang dihadapinya, baik pribadi, kelompok atau sekolah, agar terbentuk pribadi yang berakhlak mulia”. Keteladanan merupakan cara paling efektif yang sangat berpengaruh terhadap anak, baik secara pribadi maupun dalam sosial kemasyarakatan. Hal itu karena seorang pendidik merupakan contoh nyata dalam pandangan anak

Manusia bisa belajar dengan mudah mengenai kebaikan jika langsung diberi contoh dan diajak untuk praktik. Dari praktik ini para pelaku pedofilia dapat dibiasakan dalam kegiatan-kegiatan yang menumbuhkan sikap positif. Keteladanan yang paling berpengaruh adalah yang paling dekat dengan pembelajar (peserta didik). Orang tua, karib kerabat, pemimpin masyarakat dan siapapun yang sering berhubungan dengan pembelajar terutama idola pembelajar, adalah menentukan proses pembentukan karakter kuat.

\section{Tobat (kembali) kepada Allah}

Strategi ini harus dipakai untuk menyadarkan para pelaku pedofilia dan menanamkan karakter baik kepadanya.
Kesalahan-kesalahan menjadi pelaku pedofilia yang mengantarkannya kepada dosa, harus diarahkan kepada tobat yang sungguh-sungguh. Tobat adalah kembali kepada ajaran Allah yang benar setelah melakukan kesalahan dalam hidup, seperti pedofilia. Tobat nasuha adalah kembali ke jalan Allah yang benar dari dosa/kesalahan yang di perbuatnya di masa lalu dan menyesali (muhasabah dan refleksi) atas dosa-dosa yang dilakukannya serta berjanji untuk tidak melakukannya lagi dimasa mendatang untuk mewujudkan karakter baik dimasa yang akan datang. Lebih lanjut Selain Syafrudin (2017: 297) dalam penelitiannya memaparkan bahwa melalui aktifitas zikir seseorang akan mendapatkan ketenangan jiwa, terhindar dari kemaksiatan, dan mudah menyelesaikan problematika yang dihadapi karena tumbuh sifat optimis serta dapat mengendalikan diri dari keinginan hawa nafsu.

Puncak dari keenam strategi ini adalah habit of the mind, habit of the heart and habit of the hands, di mana karakter menjadi kunci utama sebuah bangsa untuk bisa menjadi maju. Jadi, strategi-strategi yang disebutkan di atas harus diterapkan kepada para pelaku pedofilia untuk mengembalikan jati dirinya kepada fitrah Allah sebagai manusia yang normal dan mengeluarkannya dari kubangan kelainan perilaku. 
Menurut tokoh lain, yaitu Thomas Lickona berpendapat bahwa pengetahuan tentang moral yang dimiliki oleh seseorang tindak cukup mengantarkan manusia menjadi individu yang berkarakter. Oleh karena itu nilai moral harus disertai dengan adanya karakter bermoral yang dimanifestasikan dalam tindakan nyata melalui tingkah laku yang baik, jujur bertanggung jawab, menghormati orang lain dan karakter mulia lainnya (Muslich, 2011:36). Dengan demikian, Thomas Lickona berpendapat bahwa karakter seseorang terbentuk melalui tiga macam komponen karakter, yaitu pengetahuan tentang moral (moral knowing), perasaan tentang moral (moral feeling) dan perbuatan moral (moral action) (Lickona, 2013: 75)

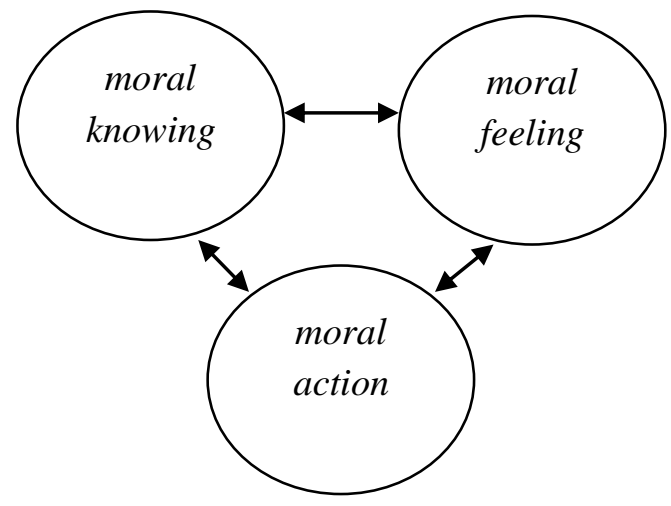

\section{Gambar. Komponem karakter baik menurut Thomas Lickona}

Adapun penjelasan komponen-komponen karakter tersebut sebagai berikut:

\section{Moral knowing}

Moral knowing adalah tahapan penguasaan pengetahuan tentang nilai-
nilai.Ada sejumlah aspek yang menonjol dalam hal ini, yaitu kesadaran moral (moral awereness), mengetahui nilai-nilai moral (knowing moral values), pengambilan perspektif (perspective taking), penalaran moral (moral reasoning), keberanian mengambil sikap (decision making), pengenalan diri (introduction), pengambilan keputusan (decision making), pengetahuan pribadi(self knowledge).Para pelaku pedofilia dalam tahap ini dibenahi pengetahuan dan sikapnya terhadap diri sendiri, seperti tugas dan kewajibannya.

\section{Moral feeling}

Moral feeling merupakan pendalaman dan penguatan aspek emosi seseorang untuk lebih menghayati mengenai pengetahuanpengetahuan tentang nilai agar menjadi manusia yang berkarakter baik. Penguatan ini bisa menjamin manusia untuk lebih ekstrem dalam menghayati jika memperhatikan aspek-aspek hati nurani (conscience), penghargaan diri (slef esteem), empati (empathy), menyukai kebaikan (love kindnees), kontrol diri (self control), krendahan hati (humility. Pada tataran inilah para pelaku pedofilia ditumbuhkan kesadarannya untuk selalu mengontrol diri dan menyukai setiap kebaikan, agar mereka tidak mengulanig perbuatannya lagi.

\section{Tindakan Moral}

Tindakan Moral atau moral action merupakan perbuatan atau tindakan moral 
dari hasil (outcome) dari dua komponen karakter yang telah disebutkan di atas. Untuk benar-benar memahami mengenai sesuatu yang menggerakkan seseorang dalam melakukan tindakan atau berbuat baik (action morally), maka harus dapat dilihat dari tiga aspek lain karakter, yaitu kompetensi (competence), keinginan (will), dan kebiasaan (habit). Di sini para pelaku pedofilia dididik secara sistematis untuk menggali kompetensi-kompetensi yang baik dan disinkronkan dengan keinginan nyata, sehingga keinginan tersebut bisa dibiasakan dalam tindakan pula.

Ketika anak menjadi sasaran dan korban dari pergerakan pedofilia, maka itu artinya ada dua hal yang harus dikoreksi, yaitu pengawasan terhadap anak kurang maksimal dan pendidikan karakter yang belum terealisasikan secara sempurna bagi pelaku pedofilia. Maka dalam hal ini, anakanak harus mendapatkan porsi pengawasan yang lebih dari biasanya. Kemanapun perginya anak-anak harus selalu dipantau dengan baik dan apapun profesi para pelaku pedofilia, dia tetap harus dididik untuk mencapai karakter yang baik

Anak merupakan amanah dari Tuhan yang harus dirawat, dijaga dan dibesarkan dengan baik dan benar. Orang tua menjadi pihak pertama dan utama dalam bertanggung jawab terhadap kesehatan dan keselamatan anak di manapun berada.Begitu juga pihak sekolah dan masyarakat, dua pihak ini turut bertanggung jawab terhadap keselamatan anak-anak dari kejahatan seksual.

Untuk menangkal gerakan pedofilia di Indonesia, selain mengaktifkan pendidikan karakter kepada para pelaku pedofilia, ketiga pihak tersebut harus bersinergi meningkatkan kewaspadaan dan pengawasan terhadap segala kegiatan anak. Ketiga pihak tersebut jangan sampai lengah dalam mengawasi anak-anak dalam setiap kegiatannya. Meningkatkan pengawasan, sama saja menutup ruang kejahatan terhadap anak sekaligus memberikan keamanan yang ekstra kepada anak. Hal yang harus dilakukan untuk meningkatkan pengawasan terhadap anak adalah pertama, identifikasi dengan siapa saja anak-anak berteman dan bergaul. Jika perlu, buatkan list teman-teman yang bergaul bersama anak-anak dan pastikan jika teman-teman bergaulnya adalah orang yang baik. Dengan data mengenai teman-teman yang telah dimiliki, maka kita bisa mengondisikan dengan mengarahkan anak-anak kita kepada siapa saja berteman dan bergaul.

Kedua, membuat tim pengawasan terhadap anak-anak yang ada di satu kelurahan sekaligus mengidentifikasi orangorang yang berpotensimelakukan kejahatan seksual terhadap anak. Tim ini untuk memperkuat benteng pengawasan terhadap anak, di sampingorang tua sebagai pengawas 
utama.Tim ini perlu dibuat, karenamelihat fakta padakasus-kasus pedofilia yang sudah terjadi (seperti kasus di Karanganyar), umumnya masyarakat tidak menaruh curiga terhadap seorang pemuda bernama Fajar yang kesehariannya tertutup dan pendiam. Masyarakat menganggap dia warga yang baik dan banyak diam, namun pada kenyataannya dia telah berbuat cabut terhadap anak-anak di bawah umur. Dengan adanya tim ini, maka masyarakat bisa mendeteksi siapa saja yang berpotensi menjadi pelaku pedofilia.

Ketiga, melakukan sosialisasi gerakan anti pedofilia terhadap masyarakat, dengan tujuan untuk membangun kerjasama agar saling waspada dan mengawasi setiap anak diri sendiri, saudara maupun tentagga.Melalui sosialisasi ini, seluruh komponen masyarakat bisa terbangun kesadarannya dalam bekerjasama mengawasi anak.

Ketatnya pengawasan terhadap anak dalam kegiatan apapun, bisa menutup celahcelah para pelaku pedofilia untuk berbuat jahat kepada anak-anak.Celah sekecil apapun, tidak akan bisa dimanfaatkan oleh mereka yang pada saat ini masih banyak memburu anak-anak lainnya.Dengan demikian, anak-anak bisa terjaga pergaulanya dan mendapatkan hak keamanan penuh dari orang tua, sekolah dan masyarakat.

\section{KESIMPULAN}

Pedofilia merupakan perilaku peyimpangan seksual, biasanya seseorang yang menderita pedofil akan menyukai anakanak sebagai sasaranya dimana perlaku memiliki ciri tersendiri seperti obsesi yang tinggi, bersifat predator danintrover. Pelaku pedofil dalam mendekati sasaranya tentu dengan tidak ceroboh karena memang pelaku memiliki rasa kasih sayang namun kasih sayang tersebut salam dalam menempatkanya. Sehingga darisini ada beberapa strategi pendidikan karakter yang perlu dilakukan dalam membina pelaku pedofil diantaranya Moral feeling dan loving merasakan dan mencintai yang baik, Moral acting tindakan yang baik, Keteladanan (moral modeling) dari lingkungan sekit, Tobat (kembali) kepada Allah. Sehingga dengan demikian para pelaku pedofil benarbenar memiliki karakter baik yang tidak sebatas terhadap pengetahuan semata namun pada pengetahuan, tindakan hingga perasaan.

\section{DAFTAR PUSTAKA}

Ahmad, S., Kristiawan, M., Tobari, T., \& Suhono, S. (2017). Desain Pembelajaran SMA Plus Negeri 2 Banyuasin III Berbasis Karakter Di Era Masyarakat Ekonomi ASEAN. Iqra': Jurnal Kajian Ilmu Pendidikan, 2(2), 403-432.

Anindyakirana, Febi. (2014).Ciri-Ciri Para Pelaku Pedofilia Anak, Bandung: CV. Pustaka Setia. 
Burhan, Bungin. (2003). Metodologi Penelitian Kualitatif, Jakarta: Raja Grafindo Persada.

Handayani, P. K. (2010). Analisis psikofenomenologi pada narapidana pelaku pedofilia, pendekatan integratif:: Studi fenomenologi dan analisis klinis (Doctoral dissertation, Universitas Gadjah Mada

Kemendiknas. (2010). Bahan Pelatihan Penguatan Metodelogi Pembelajaran Berdasarkan Nilai-Nilai Budaya Untuk Membentuk Daya Saing dan Karakter Bangsa: Pengembangan Pendidikan Budaya dan Karakter Bangsa, Jakarta: Pusat Kurikulum Badan Penelitian dan Pengembangan Kementrian Pendidikan Nasional.

Kristiawan, M. (2015). A Model of Educational Character in High School Al-Istiqamah Simpang Empat, West Pasaman, West Sumatera. Research Journal of Education, 1(2), 15-20.

Kristiawan, M. (2016). Telaah Revolusi Mental Dan Pendidikan Karakter Dalam Pembentukkan Sumber Daya Manusia Indonesia Yang Pandai dan Berakhlak Mulia. Ta'dib, 18(1), 13-25.

Kusuma, Doni. (2010). Pendidikan Karakter: Strategi Mendidik Anak di Zaman Global, Jakarta: Grasindo.

Lickona, Tomas. (2013). Pendidikan Karakter Panduan Lengkap Mendidik Siswa Menjadi Pintar dan Baik, cet. ke-1, Bandung: Nusa Media.

Maragustam. (2010). Filsafat Pendidikan Islam Menuju Pembentukan Karakter Menghadapi Arus Global, Yogyakarta: Kurnia Salam Semesta.

Muslich, Masnur, (2012). Pendidikan Karakter Menjawab Tantangan Krisis
Multidimensional, Jakarta: Bumi Aksara.

Khaidir, M. (2007), "Penyimpangan Seks (Pedofilia). Jurnal Kesehatan Masyarakat Andalas, 1 (2). 83-89

Megawangi, Ratna. (2014). Pendidikan Karakter: Solusi yang Tepat Untuk Membangun Bangsa, Bogor: Balai Pustaka.

Purwaningsih, E. (2012). Keluarga Dalam Mewujudkan Pendidikan Nilai Sebagai Upaya Mengatasi Degradasi Nilai Moral. Jurnal Pendidikan Sosiologi dan Humaniora, 1(1).

Probosiwi, R., \& Bahransyaf, D. (2015). Pedofilia dan Kekerasan Seksual: Masalah dan Perlindungan Terhadap Anak. Sosio Informa.

Renata, R., Kristiawan, M., \& Pratami, F. A. R. (2017, December). Perbincangan Pendidikan Karakter. In Prosiding Seminar Nasional Program Pascasarjana.

Samiadi, L. A. (n.d.). Penyakit Pedofilia. Retrieved March 4, 2017, from https://hellosehat.com/penyakit/pedofil ia/

Sari, Y. A., \& Suhono, S. (2017). Applaying Transition Action Detail Strategy on Written Text of EFL Young Learners. Iqra': Jurnal Kajian Ilmu Pendidikan, 2(1), 1-24.

Suhono, S. (2017). Surface Strategy Taxonomy on The EFL Students'composition A Study of Error Analysis. Iqra': Jurnal Kajian Ilmu Pendidikan, 1(2), 1-30.

Suhono, S., \& Utama, F. (2017). Keteladanan Orang Tua dan Guru dalam Pertumbuhan dan 
Perkembangan Anak Usia Dini.

Elementary: Jurnal Ilmiah

Pendidikan Dasar, 3(2), 107-119.

Syafrudin, S. (2017). Pendidikan Karakter Melalui Aktivitas Zikir. Faktor Jurnal Ilmiah Kependidikan, 4(3), 291-300.

Sunan al-Baihaqi” Juz II, Hadis No. 472, dalam Maktabah Syamilah.

Tim Pustaka Phoenix (2010), Kamus Besar Bahasa Indonesia, Jakarta: Pustaka Phoenix, 2010).

Wulandari, Y., \& Kristiawan, M. (2017). Strategi Sekolah dalam Penguatan Pendidikan Karakter Bagi Siswa dengan Memaksimalkan Peran Orang Tua. JMKSP (Jurnal Manajemen, Kepemimpinan, dan Supervisi Pendidikan), 2(2).

29 Dosen Kirim Surat Terbuka ke Wali Kota Metro. (n.d.). Retrieved January 27, 2018, from http://www.tribunnews.com/regional/2 016/05/08/29-dosen-kirim-suratterbuka-ke-wali-kota-metro 